\title{
Granite Mining Operations in Umuelema Land, Amata-Village, Community, Ishiagu 1950-2010
}

\author{
Joseph C. Chukwu (Ph.D) \\ Reader, Department of History and International Relations, Abia State University, Uturu
}

\begin{abstract}
Granite mining operations took place in some parts of Ishiagu community in the colonial and part of the postcolonial eras before the Nigerian civil war 1967-1970. The villages involved were Amonye and Amaeze village communities. The agencies of government that carried out the operation were the Nigeria Railway Corporation and the Nigeria Army Engineers. Mining activities commenced in the large expanse of land belonging to Umuelema kindred, Amata village, Ishiagu in the 1950s but increased in tempo in the 1970s following the end of the Nigeria civil war in 1970s. The war had some devastating effects on parts of the Nigerian nation, particularly Igboland which was a war theatre where virtually the entire infrastructural developments of the pre-civil war society came to the ruins. Availability of granite stones in our area of study attracted various categories of miners to the land. Labour was sourced from within and outside Ishiagu. Land lease agreements were entered into by each miner or groups of miners (leasee) and (the land owner leasers). Each party benefitted from the enterprise due to its lucrative nature.
\end{abstract}

DOI: $10.7176 /$ RHSS/11-10-04

Publication date:May $31^{\text {st }} 2021$

\subsection{INTRODUCTION}

Available evidence point to the fact that Ishiagu community is among the few communities in Igboland blessed with granite deposits. Stone mining did not take part in the entire Igboland in the pre-colonial era for the simple reason that it did not form part of the economic activities in this area during the period in question.

Among parts of the Igbo communities with granite deposits are Awgu, Lopa-ukwu, Afikpo, Uturu, Abakaliki Lekwesi and Ishiagu. Some Igbo communities that were not blessed with granite deposits, had some sedimentary rock deposits. As already indicated above, Ishiagu is specifically blessed with deposits of granite rock which was a type of igneous rock outcrop. The area is grossly deficient in sedimentary rock deposits. The demands for types of sedimentary rocks such as sand, laterites and gravels among others were met by supplies from communities outside Ishiagu. Such communities included Uturu, Isuikwuato, Ihube, Okigwe, and Enugu among other ${ }^{2}$.

Ishiagu has been popular for granite mining since the Colonial era. Parts of Ishiagu where mining operations took place during the period were Amata (our area of study), Amonye and Amaeze village communities. They were located at the western boarders of Ishiagu, along the eastern rail route running from Port-Harcourt to Enugu. The Nigeria Railway Corporation and the Nigeria Army Engineers were prominent agencies of the Federal Government involved in granite mining activities in the colonial and post-colonial eras before the close of the Nigeria civil war in 1970. Private miners also took part in the mining operations in our area of study. As noted above, the civil war, which caused some colossal devastation of human and material resources across the nation, particularly Igboland, the major war theatre, stimulated the urgent need for construction, reconstruction and rehabilitation of damaged infrastructure in parts of Igboland. The urgent need for the reconstruction and rehabilitation of projects across the war battered Igboland was expressed in the speech of the then Head of State, General Yakubu Gowon, who saw the Nigeria civil war an unfortunate incident among brothers of the nation. Thus he declared that the war ended without any "Victor or Vanquish" 3 . In order to revive the relationship that had existed among the Igbo and other Nigerians across the nation; the Head of stated announced a policy and programme of "Reconciliation, Reconstruction and Rehabilitation"4. Realization of this project was made possible by the vibrant nature of the Nigeria's economy at that period, following the rise in Nigeria's oil price in the $1970 \mathrm{~s}^{5}$.

By the 1970s individual miners, private company miners, corporate bodies were in search of sedimentary rocks and granite rocks to meet the demands for various construction and rehabilitation projects going on in parts of Igboland. Ishiagu community had already been noted and identified for granite deposit deposits across its lengths and breaths. Individual and corporate bodies at the time explored granite deposits in parts of the Ishiagu community. The Railway Corporation maintained its control of granite rock deposits at Amonye and Amaeze village communities; Moniar Construction Company (MCC) and later Crushed Rock Industries settled for Amokwe rocky hill, while a large number of private miners settled at various parts of Ihie, Okue, Ogwor and Amokwo villages where they carried out their granite mining activities to meet the granite demands of contractors and other customers for granite supplies for their construction and rehabilitation projects across Igboland and beyond. 
Apart from the above villages, granite mining took place in a larger scale in our area of study Umuelema land, a large expanse of kindred land at the farmstead far withdrawn from the homestead. This was a granite stone ridden land belonging to umuelema kindred in Amata village, Ishiagu ${ }^{6}$. A number of individual miners and even corporate bodies found their ways into this territory at different times from 1950s upwards. Among the miners there were Aro Nweke, Uche Nwajah, Chief Onyeso Nwachukwu, Ezekiel Ehibudu, Stephen Ofomata and Dennis Nwachukwu (Dengroupco Nig Ltd), among others ${ }^{7}$. In this essay, efforts are made to discuss the nature and method of operation of each miner, labour force used, types of equipment applied, relationship between miners and land owners; finally, the general impact of the mining activities in this area of study will be investigated and highlighted.

\subsection{GRANITE MINING AT EKETE (UGWU-OMOBO/OKPOME) LAND, AMATA VILLAGE, ISHIAGU,}

This was the first granite site in our area of study in the post-Nigeria Civil war era. Granite mining had taken place there before the civil war. This site was a distance of about two kilometers from the Nigeria Railway Corporation mining site at Ugwu-Amalokpa, Amonye Ishiago ${ }^{8}$. But, it was worked by private individuals. Aro Nweke acquired the Ekete (Eke-Nta) land, while Uche Nwajah acquired the land at Ugwuomobo'. These two men were former employees of the Nigeria Railway Corporation who worked at Ugwu-Amalokpa, Amonye, site, as granite miners. It was there they acquired the skill of mining before they left the Railway employment and settled for their private employments in these sites since 1950. They mined and quarried granite stones which they later sold to the Railway Corporation before the civil war. Private individuals and companies also bought from them. Among he contractors that patronized these miners in the 1960s were Stev Evuleocha Group of companies who came to the site to buy granite for its contracts. Another company was Guffanti-Boniger Nig. Ltd. This was a construction firm that handled the road construction project from Afikpo to Okigwe between 1962 and 1963. Guffanti mounted an asphalt base near Afikpo Road Railway Station, Ishiagu ${ }^{11}$.

In the early $1960 \mathrm{~s}$, a cubic yard cost five shillings. Later the price rose to seven shillings $(7 \mathrm{~s})^{12}$. A trip of 5 cubic yard cost two pounds, ten shillings (£2:10s). Stones were measured not by weight, but by size ${ }^{13}$. So, lumps were arranged in heaps $3 \mathrm{ft}$ high, $3 \mathrm{ft}$ wide and $3 \mathrm{ft}$ long. ${ }^{14}$

By 1970 when the war ended, people expected mining and quarrying of granite to resume at these sites. But this did not happen in any of the sites. The reason was that Aro Nweke and Uche Nwajah who enlisted in the Biafran army died in the $\operatorname{war}^{15}$. But the sites were already popular for granite mining and their chipping products. Besides, granite stones were badly needed immediately after the civil war to carry out various reconstruction and rehabilitation projects particularly in the war battered East Central State. On their own part, the land-owners who incidentally were victims of the civil war were eager to welcome miners on their land, although on new terms and condition that would guarantee some revenue for the family rehabilitation ${ }^{16}$. In the past, virtually nothing was charged, and the miners did not enter into any written agreement with land owners. But this time the story was different. Potential miners on any part of the land were required first to sign an agreement with the owners and at the same time pay rents to them ${ }^{17}$.

\subsection{CHIEF ONYESO NWACHUKWU MINING OUTFIT}

Chief Onyeso Nwachukwu was the first to commence mining at Ekete hill in 1970. He acquired the land from Umuelema kindred, Amata Ishiagu, under lease agreement. This lease was for 99-year duration. The lease was only for granite quarry and not for any other purpose. If any other mineral was discovered in that land/ according to the agreement, a fresh agreement would be entered into for that purpose ${ }^{18}$. According to the agreement too, Onyeso Nwachukwu was to pay to Umuelema family a royalty of one guinea (£l:ls) annually. Umuelema family in turn would not unduly interfere with the activities of the miner (tenant) ${ }^{19}$.

Onyeso Nwachukwu employed the services of many Ishiagu indigenes for his mining operations. Some non-Ishiagu people were also employed for various skills, such as, land clearing tasks, erection of booths, security out fit and drilling activities.

\section{a) Land Clearing:}

The first few men employed by Onyeso Nwachukwu in September 1970 were engaged in clearing the site of weeds and other vegetations. They were unskilled labourers who received their pay at the end of the day's exercise $^{20}$

\section{b) Erection of Booths:}

Some local carpenters were employed to erect some make-shift buildings at the site. These were used for the storage of implements and equipments of the company. This task was in form of a contract. At the completion of the assignments the carpenters were paid their money and their business with the company terminated.

\section{c) Security Men:}

Another set of workers employed by Onyeso Nwachukwu were security men. After erecting booths at the site, there was the need to move into the site very important implements and equipments of the company. For the 
security of the equipments, able-bodied men were employed. Many of the security men were from Amata Ishiagu. Others came from outside Ishiagu. Among these were John Ukpai and Nwaokoro Mbechi from Amata Ishiagu who were chief security men of this outfit ${ }^{22}$. The security men worked only in the nights and were therefore called "Watch Nights". The security men were not equipped with guns by the company. They rather went to work with their cutlasses. Their job was to scare anyone from coming into the site premises to steal any property of the company. They received their pay at the end of each month ${ }^{23}$.

\section{d) Drillers}

Drillers were among the skilled workers of the company. Among the drillers employed by the company were Peter Amuwa from Umuahla and Okorie Nwagwu from Okigwe ${ }^{24}$. Drilling was the first major step in granite mining and quarry. Onyeso Nwachukwu was the first granite miner at Ishiagu to make use of hand-drilling machine. His predecessors, the Nigeria Railway Corporation at Amalokpa site, Aro Nweke and Uche Nwaja who previously mined at Ekete site before the Nigeria Civil war did not use hand-driller. Rather, these predecessors made use of sledge hammer to drive in long chisels into the bed-rock before explosion took place. But Onyeso used hand-drilling machine which was powered by a generating $\operatorname{set}^{25}$. The hand driller was pressed firmly and steadily on a bed-rock, while it was connected to the generating set. As the generator was on, the long rod of the drilling machine which had direct contact with the bed-rock commenced threading and drilling right inside the bed-rock. By the time the rod of the drilling machine was completely sunk into the bed-rock, the next stage began. This was explosion stage ${ }^{26}$.

e) Explosion:

Another set of skilled workers of the company were those incharge of explosives. Among these skilled workers wee Maxwell Oji from Ishiagu and Reuben Osi, also from Ishiagu ${ }^{27}$. The explosive chemical they used was dynamite. During explosion, enough security measures had to be put in place to avoid any casualty. Workers were made to clear from the site, and even nearby villagers were adequately warned to take cover to avoid flakes of stones inflicting serious wounds on them. At the end of the explosion, whistle was then blown to inform the people that the explosion exercise was over ${ }^{28}$. When this happened another stage of the mining/quarrying exercise commenced. This was lifting of lumps from mining site to quarry site.

\section{f) Lump Carriers:}

There were a large number of people employed to hew out and carry lumps of stone from the pit to the crushing section. They used hammers and chisels to hew out quantities of the stone they could carry with head-pans, to the crushing site. This took place at the end of explosion exercise. There were no pay-loader caterpillar trucks and tippers at that time to perform these functions as was the case with modern miners in the late 1970s onwards ${ }^{29}$

Because the crushing machine used by Onyeso Nwachukwu was of a small size, he also employed the services of men and women who had acquired the skill of stone crushing ${ }^{30}$. Sizes of stone produced were $1 / 2$ inch, $3 / 8$ inch and lumps. These various sizes of stone were sold to various contracting firms and individuals who used them for construction of roads, culverts, airports and stadia, among others ${ }^{31}$. However, Chief Onyeso used the larger portion of the products for his construction projects in various parts of East Central State ${ }^{32}$.

Chief Nwachukwu was a gentleman. According to a member of the Umuelema landlord family "Chief Nwachukwu fulfilled all the responsibilities required of him as contained in the agreement of 1970. He did not cheat anybody" 33 . At the same time he did not make any contribution to the community beyond that provided for in the agreement ${ }^{34}$. Unfortunately the said agreement was never made available to the author. All efforts made to get at it were futile. His contract ended in 1975 and was not renewed ${ }^{35}$. No reason was given for not renewing it. But one can suggest certain reasons for this. If his contracts across the East Central State had been completed it would be unprofitable to continue in the business since the bulk of the products were utilized by his company for his contracts across the state. Besides, from 1974 onwards, modern granite mining companies had commenced operations in various communities of ishiagu. These included Monier Construction company, (MCC) Fourgerolle Nig. Ltd, Crushed Rock industries and Dumez among others. These operated with very sophisticated equipments beyond the scope of Onyeso. It is possible Chief Nwachukwu got scared by the advent of these companies in the same business environment with him. So he quietly pulled out of the scene.

Another miner that came to the area was Ezekiel Ehibudu. The activities of this miner will be discussed in the successive passages.

\subsection{EZEKIEL EHIBUDU GRANITE MINING AT OPIELE IKPACHI, AMATA VILLAGE, ISHIAGU IN 1975}

Ezekiel hailed from Amaiyi Obilohia village in Ogudu-Asa community in Isuikwuato Division of East Central State ${ }^{36}$. On 10 August 1975, he entered into an agreement with Umuelema family for the purposes of granite mining at a portion of their land at Opiele Ikpachi ${ }^{37}$. The highlights of the agreement were as follows.

i) The landlord was to let and the tenant was to take the piece of land situated and known as Opiele Ikpachi, and measuring 17.082 hectares, for the purpose of quarrying venture. 
ii) That Ezekiel Ehibundu as a tenant should on his part pay to Umuelema family, as landlord, a lease fee of (50k) fifty kobo for each tipper lorry load of stone he moved.

iii) That a total sum of twenty naira, two packets of cigarette, two jars of palm wine, (4) four cartons of beer and a goat should be presented to the landlord by the tenant on the day the agreement was to be signed, as customary benefits.

iv) It was also agreed that as long as the tenant consistently paid the agreed rents as well as observe the conditions here-in contained in the agreement, he would be free to use the land without any interruption by the landlord or any person lawfully claiming under him. The land in question came under survey lease No. E/QLS 4293. Tracing No. AB105/94.

v) The agreement was for a five year duration. It was therefore renewable after five years ${ }^{38}$.

By this agreement with the landlords, Ehibudu commenced mining on the site. He employed the services of Ishiagu indigenes that were already skilled in granite mining. Like Onyeso Nwachukwu, he made use of a drilling machine powered by a generating set. Explosives were used to blow up a bed-rock at the end of a drilling exercise. Dynamite was the explosive chemical also used by Ehibudu.

At the end of explosion, a group of workers with chisels and hammers hewed out lumps of stones which they carried to the granite site, using head-pans. Unlike Onyeso Nwachukwu, he made exclusive use of manual crackers. There was no crushing machine at the site for the five years he operated there.

Mr. Ehibudu produced and sold chippings to private companies and individuals who needed them. He did not renew the agreement for a second term. An informant said he exhausted the granite deposits at the site, and instead of wasting time producing a mixture of granite and shales there, he opted to fold up ${ }^{39}$. Another company that came to quarry at Umuelema family land at Amata Ishiagu was Stephen Ofomata Private Company.

\subsection{AN AGREEMENT BETWEEN MR STEPHEN OFOMATA AND UMUELEMA FAMILY, AMATA, WAS DATED 27 JUNE, 1973}

This agreement made this 27th day of June 1973 between Messrs (1) Okoro Chukwu (2) Orji Ogbonnaya (3) Boy Aja and (4) Okeke Osi, accredited representatives of Umuelema quarters, Amata Ishiagu for themselves and on behalf of Umuelema in Amata Ishiagu (here-in after called the land-lords) which expression shall where the context admit include their heirs, successor in title or assigns of one part; and Mr. Stephen E. Ofomata, Managing Director of Ofomata \& Sons Enterprises of No. 19, Niba street Ogbete Enugu (here-in after called the leasee) which expression shall where the context admits include his heirs, administrators, successors, in title or assigns, of the second part ${ }^{40}$.

\section{Witnesseth}

1) That the landlord will lease to the leasee the piece of land at Umuelema Quarters, Ishiagu, known as and called Okpo-Mkpume Ikpachi. The Ikpachi land is bounded to the West by lokpa-ukwu and East by Ihetutu village, Ishiagu.

2) The leasee shall have the exclusive right to extract, excavate, quarry and or crush stones only in the area mentioned in paragraph I of this agreement, for a period of 99 years (ninety nine years) at the first instance.

3) That the landlord shall be entitled to receive a sum of (thirty kobo), for every tipper load of 5 (five) cubic yards of stone or mineral extracted from, the land here-unto delimited.

4) That at the end of the five years after the execution of this agreement, the agreed sum of (30k) thirty kobo payable for tipper load shall be revised.

5) The leasee is hereby authorized to take possession of the said land and to survey or beacon the parcel of land aforesaid of the Federal Ministry of Mines and Power ${ }^{41}$.

A careful perusal of this agreement would reveal some certainties in it. One was the generosity and honesty of the landlords (leaser). This was demonstrated in the clause of the agreement which allowed the leasee "exclusive right to extract, excavate, quarry and or crush stones in the area for a period of ninety nine years". The generosity of the leaser comes into greater lime-light when one considers the fact that the leaser was neither a relation of Umuelema family nor an Ishiagu indigene. He was indeed a stranger element. Yet he was accorded such a right. Even the customary rights the leasee was required to fulfill was considerate.

In any case, by this agreement, Mr. S.E. Ofomata'and company settled down to quarry at Okpome Opiele Ikpa-Achi. It would have been possible to assess the leasee, Mr. S. E. Ofomata based on his ability or inability to comply to the terms of the agreement. But he did not quarry for long. He had just quarried for one year when crisis ensued. A land hungry man, Denis Nwachukwu and his company Dengroupco Nig. Ltd encroached on the very land leased to S.E. Ofomata, claiming it was part of Lokpa-ukwu land leased to him by the Lokpa-ukwu people before the Nigeria civil war ${ }^{42}$.

Dengroupco displayed his sign board in the area. A warning board was also mounted warning all intruders to stay clear of the area. He also set up pillars with numbers and marks to establish himself a rightful leasee of the land. This certainly was frustrating to Mr. Stephen E. Ofomata and company who could not proceed with 
their mining operation under such a charged atmosphere.

At this point Umuelema family demonstrated their honesty and sincerity of purpose. They did not back out; of the deal. Rather they stood firm on their claim of ownership of the land. They also accepted they gave the piece of land to Mr. S.E. Ofomata on lease and insisted that Dengroupco must quit the land.

First, Umuelema family wrote to the Managing Director, Dengroupco a letter dated $23^{\text {rd }}$ May, 1974 and captioned "INFORMATION FOR TRESPASS - OKPOMKPUME OPIELE IKPA-ACHI LAND". The letter is reproduced here under:

This is to inform you that your team of workers and surveyors willfully and consciously entered and trespassed into our land known and called Okpomkpume Opiele Ikpachi Land already leased and surveyed by Mr. S.E. Ofomata and Sons Enterprises for quarry purposes. Please take immediate precaution to remove all your company's emblems of surveying the said land to avoid troubles and court actions immediately. The land is for Umuelema ofAmata village, Ishiagu, Afikpo Division, and not Lokpa - Ukwu in Okigwe Division.. ${ }^{43}$

This letter was signed by Okoro Onu and Boy Aja, on behalf of Umuelema family. Another letter was written to the senior Divisional Officer, Okigwe Division, by Umuelema Family on the same subject matter. They letter dated 6 June, 1974 and captioned "APPEAL TO QUIT" reads thus:

We the undersigned names humbly report to you that Messrs Dengroupco and his agent Keneth willfully and consciously entered and surveyed our pieces of lands, which we have leased to Messrs Ofomata and Sons Enterprises for years without our knowledge and approval, for quarry purposes. We pray the senior Divisional officer to warn these people to stop enlarging into the land known and called Okpomkpume Opiele Ikpa Achi of Umuelema family, Ishiagu, Afikpo Division and avoid trouble. That we appeal to these people to urgently quit the land and remove all their company's emblems for surveying, viz - Dengroupco company's posts- CBI, CB2, and CB5 posts date (May, 1974). Dengroupco is working at Lokpa-ukwu an4 what motivated him to enter into our land, we don't know. In conclusion we wish to state that we want peace and that is why we appealed and reported to you before any other further action. Tell Mr. Keneth of Lokpa-ukwu, a councilor, and Dengroupco to remove all their sign posts without further delay ${ }^{44}$.

This letter was signed by Boy Aja, Okoro Onu, and Chukwu Oti. A look at the two letters would reveal that Umuelema family was polite, peace-loving and law-abiding.

Umuelema did not apply force, to check the encroachment of Dengroupco on the land. They took to petitions to the managing director of Dengroupco and the Divisional Officer incharge of Okigwe Division. There is no evidence to show that the Divisional Officer for Okigwe reacted to the letter to him. This land dispute lingered up to 8 August, 2003, when Dengroupco capitulated and entered into agreement with Umuelema family on the lease of the said land ${ }^{45}$.

We shall now consider the agreement Umuelema family had with Dengroupco. We will also discuss how Dengroupco quarried on the land ${ }^{46}$.

\subsection{AGREEMENT BETWEEN UMUELEMA FAMILY, AMATA ISHIAGU AND DENGROUPCO NIG. LTD, WITH HEAD OFFICE AT 48 ZIK AVENUE, UWANI ENUGU}

This agreement was signed on 8 August, 2003 by both parties. Highlights of the agreement were as follows.

1) The landlords of the piece of land were specifically mentioned as Umuelema family, Amata. The name of the farmstead where the piece of land situated was given as Okpukpo Nkpume. The particular land area leased was clearly delineated.

2) The specific solid mineral to be mined was clearly described as granite. This meant that in the event of discovery of another mineral in the area, the miner must not go ahead to mine it until another agreement was written in respect of the new solid mineral to be mined.

3) Finally, there was the base-line of the agreement. The grantors agreed to allow the grantee the said land for the purposes of prospecting, mining, quarrying and crushing of granite (dolerite) stones at an annual rent of (N230,000.00) Two Hundred and Thirty Thousand naira, In addition the grantee accepted to pay the sum of $(\mathrm{N} 20,000.00)$ Twenty thousand naira to guarantor as scholarship support fund for the education of guarantor children annually. The guarantee also agreed to supply to the guarantor some thirty tons of chippings annually or in the alternative pay the guarantor its equivalent in cash. Further still, the guarantee accepted to give Christmas bonus to the guarantor annually and to give priority to Umuelema family in terms of employment opportunities ${ }^{47}$.

Dengroupco was known for easily accepting terms of agreement; it was also notorious for not complying to any terms of agreement it had earlier accepted to keep. The major weakness of this and other agreements reached 
by Umuelema and other companies was absence of means of enforcing compliance on the part of the guarantee or leasee. Most often than not the guarantee would mobilize enough money to pay annual rent and meet other requirements for signing the agreement the first year. For four years out of the five years the agreement was supposed to last, the guarantee would be dodging and meandering, making sure he avoided the guarantor. This habit among guarantee had been at the root of crisis between both parties. One would suggest a situation the grantor was made to pay up all monies and meet all other conditions for the duration of the agreement before the document was signed. In the alternative, signing of agreement should be annual affairs. So, if the company (guarantee) failed to satisfy the conditionality for the agreement to be signed, then the' signing of the agreement would not take place. After all, it was a business venture. A business outfit could decide to operate without allowing customers to purchase its products on credit.

\subsection{Method of Operation}

An informant was of the view that Dengroupco was never a renowned or popular miner. It was more concerned with acquiring people's land by tricks and sub-letting same to mult-national companies who paid him well for using the land for quarry. But in the case of this land it could not achieve this purpose. So, it decided to undertake the quarry itself ${ }^{48}$. Dengroupco therefore went into small scale mining and quarry. It produced only for private individuals and a few private companies that made use of granite chipping for building private residential and public buildings ${ }^{49}$.

Dengroupco failed to apply modern mining/quarrying techniques. Rather it used hand-drilling machines. Occasionally, it employed the services of manual drillers who used sledge hammer to drive in long chisels into the bed-rock for the purpose of drilling. This was one of the oldest techniques of drilling used even before the Nigeria civil war. It applied dynamite explosives to blow-up the drilled rock. Instead of installing a crushing machine for cracking lumps of stones, Dengroupco rather employed local stone crackers from Ishiagu and neighbouring communities ${ }^{50}$.

Its operation was an unsteady one. In the rainy season, it could not operate because of pools of water that filled the mining pits. The company failed to install a water draining pump which could be used to drain the mining pits and thus permitting year round production. The company was also said to be fond of owing its workers arrears of wages and salaries. Furthermore, it was alleged that the company was principally there to acquire land and not to produce chippings ${ }^{51}$. Continuing the source said "the company was full of tricks; it would neither fulfill the terms in the agreement it entered into with the landlord (guarantor) nor would it honourably pull out of the land. Apart from this agreement reached with the guarantor in 2003, the company (guarantee), never made efforts to renew or revise the agreement it entered into with the landlord (guarantor), nor would it honourably pull out of the land ${ }^{52}$. Rather, it would always look for holes in the agreement to capitalize and exploit in its own favour and against the guarantor ${ }^{53}$

Before this agreement was eventually reached with Dengroupco (who forcefully encroached on the land since 1974), a section of the land had been leased to Mr. Raphael C.O. Obasidey for the purpose of granite mining and quarry. Highlights of the agreement were as follows.

6.0 AGREEMENT BETWEEN (1) Chukwu Elema (2) Okoro Onu Elema (3) Dickson Osi (4) Orjinta Ogbonnia (for themselves and on belief of all members of Umuelema family) in Amata village, Ishiagu town, Ohaozara LGA, of Abia State of Nigeria, AND Mr. Raphael C.O. Obasidey of Maku Town in Awgu Local Government Area of Enugu state of Nigeria, for landed property known and called "Okpo-Nkpume Ikpa-Achi land dated $5^{\text {th }}$ February, $1992^{54}$.

\subsection{Whereby it is Agreed as Follows:}

1) The tenancy shall be for a term of 99 nine years effective from 1992.

2) The rent reserved shall be the sum of (N7,000.00) Seven thousand naira per annum.

3) There will be a period of grace for one year before commencement of payment of annual rent. That is to say that the leasee will not pay rent for the year 1992.

The rent now due for the first year will be paid at the expiration of the one year moratorium. There will however be (4) four months of grace after due date for payment of annual rent in each rent period.

\subsection{The Leasee Hereby Covenants with the Landlord as follows:}

1) To pay the said rent reserved, or the revised rent at the times and in the manner aforesaid.

2) The leasee is at liberty to enter into partnership with any person or firm for the efficient carrying on of the business, AND is authorized •to give out a portion or portions of the land to any person or firm to ensure increased productivity.

3) The leasee hereby agrees to employ members of the land lord family and reserves the right to expel such person or persons for acts of stealing the company's property, indiscipline, fraud, 
inefficiency or any act which will be detrimental to the progress of the work of the leasee.

4) The landlord hereby covenants with the leasee that the leasee, paying the said rent and observing and performing all his obligations under this agreement shall quietly enjoy the said land without interruption by the landlord ${ }^{55}$.

Based on the terms of this agreement one can make some observations. The generosity of the leaser was further demonstrated here. Apart from conceding the leasee a tenancy period of (99) ninety nine years, the leaser went ahead to approve a one year period of grace for the leasee. This thus waved for the leasee the rent of 1992. No reason was given for this unmerited favour. This too was never the practice at the time. Obasidey could be said to be the only company in the long history of granite mining to receive such a favour. To get at the reason behind this unusual generosity one would tend to consider some agitations over land ownership in the area at the time. We have just discussed Dengroupco's agitation and dispute in the area. As we will see later, a granite mining company by name Consolidated Construction Company was also some where encroaching on the land. It was possible the landlords had to do anything within their power to fraternize with and retain any interested company that came to work there through them.

To ensure the land was effectively occupied by companies approved by them, the leaser allowed the leasee not only to enter into partnership with any person or firm for its efficient business operation, but also the freedom to give out a position or portions of the land to any person or firm to ensure increased productivity. This was perhaps to ensure that whichever company that operated anywhere on the land acknowledged the over lordship of the leaser.

There is one clause in this agreement that has occurred almost in every other agreement between landlords and granite mining companies. This is the issue of the mining company promising to offer job to indigenes of host community. In this case, the promise was to family members of Umuelema, the leaser. At first it looked attractive to both parties. Both the Leaser and the leasee would see it as bait to woe the other to his side. Over the decades there has never been a success story about such clause. Rather it severally turned to be a source of rift for both parties in the end. Obasidey like Ofomata did not operate for so long before he ran into trouble. Perhaps this was why the issue of employment of indigenes by the company did not degenerate into crisis between the two parties as could be noticed in other places.

\subsection{Method of Operation}

Mr. Raphael C.O. Obasidey was a building and road contractor. He had projects at Enugu, Awka, Onitsha and Okigwe, among other towns and cities. He produced stones mainly for his contract projects. However, he sold to a few private individuals who came to buy from him.

He made use of hand-drilling machines powered by a generating set. Like others he applied explosives to blow-up the drilled bed-rock. After that lumps of the shattered bed-rock were lifted by pay-loader caterpillar into tipper (truck) that evacuated them to the crushing site. He installed a small size crushing machine which crushed the lumps into sizes as shown below:

\subsection{Sizes and Description of Granite Stone Produced.}

\begin{tabular}{|l|l|}
\hline \multicolumn{1}{|c|}{ SIZE } & \\
\hline $0-5 \mathrm{~mm}$ & Granite sand/Dust \\
\hline $0-50 \mathrm{~mm}$ & Granite aggregate \\
\hline $2-10 \mathrm{~mm}$ & Granite aggregate \\
\hline $5 / 15 \mathrm{~mm}$ & Granite aggregate \\
\hline $10 / 1 \mathrm{Smm}$ & Granite aggregate \\
\hline $15 / 22 \mathrm{~mm}$ & Granite aggregate. \\
\hline
\end{tabular}

\section{Table 1 source: Administrative office, company's site, Amata, Ishiagu.}

These stones were loaded into tippers or trailers and carried to destinations approved by the company or the individuals that paid for them. Obasidey did not operate for long before he ran into trouble with Consolidated Construction company over land issue.

\section{Conclusion}

Umuelema kindred land was a typical example of the areas where granite mining activities took place in Igboland. This exercise contributed immensely to the growth of the economy of the colonial state of Nigeria. Individual and groups were engaged in the mining activities on part time and even full time basis.

A number of factors played roles in encouraging the growth and development of this enterprise there. Among the factors were availability of granite deposits in appreciable quantities in the area; availability of labour, skilled and semi-skilled, was also a major contributive factor to the success of the enterprise. These were also the issue of accessibility. The strategic location of the Umuelema family land where it is linked to access 
roads made the place accessible to various peoples and companies who came to make purchases of the granite chippings.

The peaceful conditions that prevailed throughout the period of the mining activities were a big plus to the successful operations at the umuelema kindred land. The leasers and the leases demonstrated a good sense of cooperation. The land lease agreement too provided a good guide for harmonious and honest transactions between the parties involved. Finally, the high demands for the product and the ability of the miners at any given time to meet the demands made veritable contributions to the socio-economic development of the Igbo nation at large and Ishiagu community in particular.

\section{NOTES/REFERENCES}

1. All the Economic Historians are in agreement that the mainstay of the traditional pre-colonial Igbo economy was based on agriculture, non-agricultural production (local industries) and trade. No one conceived mining activities as part of this economy.

2. Magnus Okoro, dealer on stone haulage business, aged 65 years, interviewed at Mile 2 Ishiagu on 7 August, 2007.

3. East Central State Ministry of Information and Home Affairs; Progress in Reconstruction", Enugu; Government printed, N.D, P.1, Quoted in Paul Obi-ani, Post Civil war Social and Economic Reconstruction of Igboland; Enugu: Mikson press, 1998, p.28.

4. Ibid

5. Ibid

6. Magnus Okoro, interview cited above.

7. Magnus Okoro, interview cited above.

8. Oji Ngwoke, Stone haulage dealer / Community leader, aged 63 years, interviewed at Amata village, Ishiagu on 12 September, 2007.

9. Oji Ngwoke, interview cited above.

10. Oji Ngwoke, interview cited above.

11. Oji Ngwoke, interview cited above.

12. Michael Onuoha, Stone miner, aged 60 years interviewed on 16 January, 2008 at Amata village, Ishiagu

13. Michael Onuoha, interview cited above.

14. Michael Onuoha, interview cited above

15. Michael Onuoha, interview above

16. Bartholomew Okoro, a private granite miner aged 66 years, interviewed at Amata village, Ishiagu on 8 April, 2008.

17 Bartholomew Okorie, interview cited above.

18. Bartholomew Okorie, interview cited above.

19. Bartholomew Okorie, interview cited above.

20. Michael Ude-Osi, a former staff of Onyeso Nwachukwu's private company, aged 64 years, interviewed on 28 April, 2007 at Amata village, Ishiagu.

21. Michael Ude-Osi, interview cited above

22. Gabriel Okochi, a teacher and Community Leader, 57 years, interviewed on 5 May, 2007 at Amata village Ishiagu.

23. Gabriel Ude-Osi interview cited above

24. Martin Okechukwu, former staff of Onyeso Nwachukwu's company interviewed at Amata on 6 April, 2007.

25. Martin Okechukwu, interview cited above.

26. Martin Okechukwu, interview cited above.

27. Martin Okechukwu, interview cited above.

28. Martin Okechukwu, interview cited above.

29. Martin Okechukwu, interview cited above.

30. Martin Okechukwu, interview cited above.

31. Martin Okechukwu, interview cited above.

32. Martin Okechukwu, interview cited above.

33. Silas Okoro - Elema, Aged 57 years, a businessman and member of the land owner family, interviewed on 7 May, 2007, at Amata village, Ishiagu

34. Silas Okoro-Elema, interview cited above

35. Silas Okoro-Elema, interview cited above

36. Ezekiel Ehibudu was a private company granite miner. He hailed from Oguduasa community, Isuikwuato and he was among the early miners at umuelema land,Ameta village, Ishiagu.

37. Land agreement between Ezekiel Ehibudu and Land-Owners, Umuelema kindred, Amata village, Ishiagu dated 10 August, 1975. 
38. Boniface Okoro-Elema, interview cited above.

39. Boniface Okoro-Elema, interview cited above.

40. Land lease agreement between Umuelema family (leaser) and Mr. Stephen Ofomata (lease) dated 27 May, 1973.

41. Ibid

42. P.S Arum a teacher aged 52 years interviewed on 8 June, 2008 at Amata village Ishiagu.

43. This represents a verbatim copy sent to the Director of DenGroupCo's by Umuelema, family warning her to withdraw from their land it illegally occupied

44. This was a copy of another letter written by the Umuelema family to the Divisional Officer, Okigwe on the subject matter of land issue.

45. P.S. Arum, interview cited above.

46. P.S. Arum, interview cited above.

47. This was the content of the land lease agreement between the Umuelema family and Dengroupco, dated 8 August 2003, and signed by both parties.

48. Augustine Ude a private granite miner, aged 56 years, interviewed on 8 April 2007 at Amata village, Ishiagu.

49. Augustine Ude, interview cited above.

50. Augustine Ude, interview cited above.

51. Augustine Ude, interview cited above.

52. Augustine Ude, interview cited above.

53. Augustine Ude, interview cited above.

54. These were the signatories to the land lease agreement between Mr. Raphael C. O. Obasidey and Umuelema family, dated 5 February, 1992.

55. Terms of the land lease agreement between Umuelema land owner and Raphael, C. O. Obasedey dated 5 February, 1992.

56. Table I reflects the sizes of granite chippings produced by Mr. Raphael C.O. Obasedey Company. 